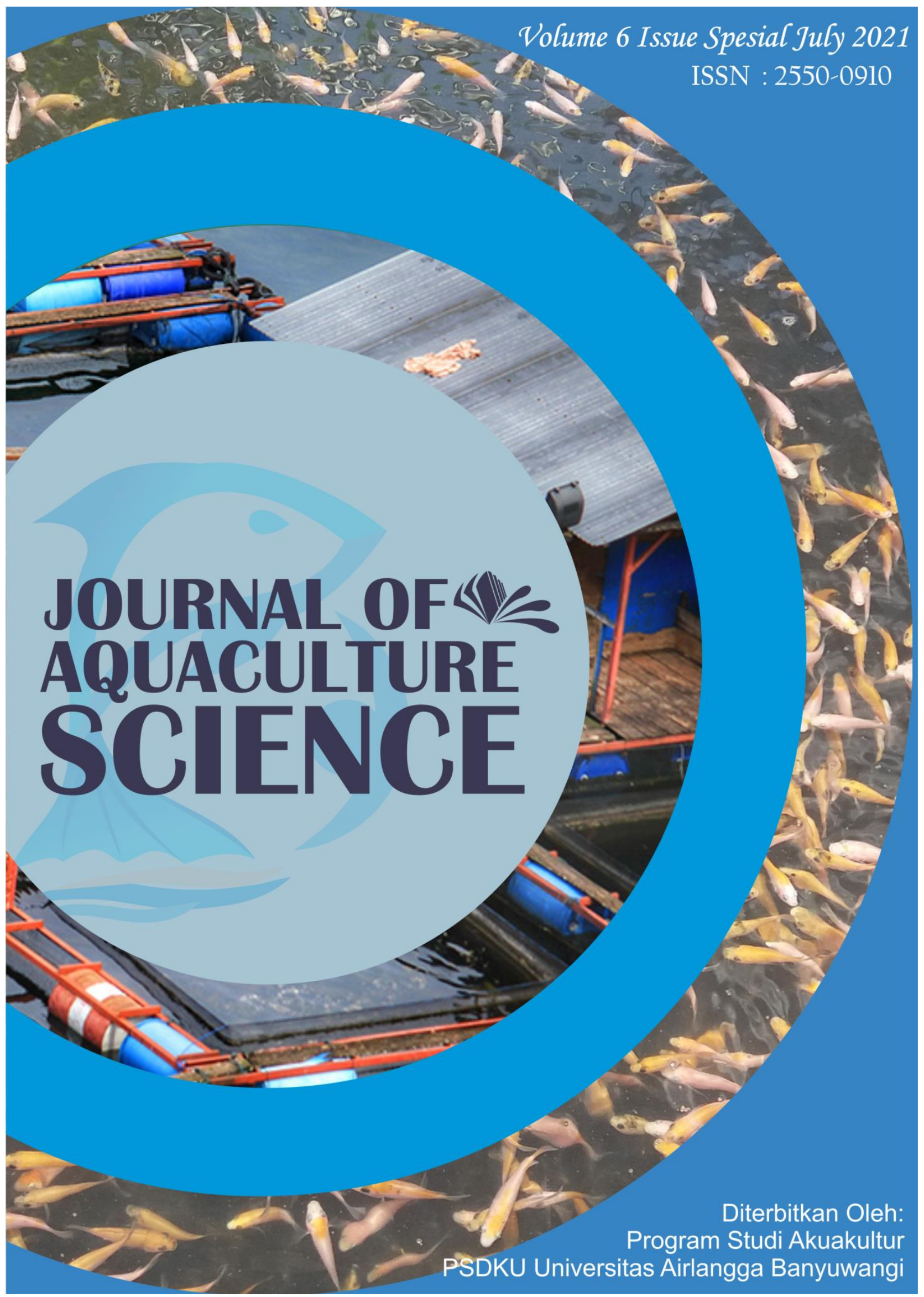




\section{Author Index}

\section{Volume 6 Number 1 Issue Spesial July 2021}

Abdul Muqsith 110

Abdul Wafi 110

Ach. Khumaidi 110

Achmad Fuad Fathurrahman 134

Ade Prasetyo Abdi 52

Adinda Diah Adyaningrum 119

Agustina Tri Kusuma Dewi 268

Ahmad Rido'i Yuda Prayogi 44

Amriana 134

Amriana Amriana 164

Arif Habib Fasya 52

Asfarina Hidayah 37; 119; 192

Chyntabela Puspita Martha 148

Dandy Prasetiyo 164

Darmawan Setia Budi 1

Dede Hartono 231

Diana Arfiati 97

Dimas Imaniar 183; 198; 208

Dini Alvateha 97

Edrial 77

Elok Rosyidah 90

Endang Suhesti 218

Erna Agustina 208

Ervina Wahyu Setyaningrum 15

Fidhiyah Dita 97

Gatut Bintoro 61

Idham Malik 134

Ieke Wulan Ayu 77

Irwan Kurniawan Soetijono 148

Kanthi Pangestuning Prapti 245

Magdalena Putri Nugrahani 268

Marwiyah 148

\section{Mega Yuniartik 15; 268}

Moh. Fahrurrozi 157

Mohammad Faizal Ulkhaq 52

Muh Azril 164

Muhammad Arief 1

Muhammad Arif Rahman 61

Muhammad Reynaldy Thoriq Al Islam 1

Nindi 61

Nita Hellis Setyowati 61

Nur Ahyani 164

R. Dravendy Marta Ishardhi 157

Rizky Kusma Pratiwi 97

Rudi Mulyanto 148

Rusdi Abdat 44

Safrieta Jatu Permatasari 183

Sahru Romadloni 90

Septyan Andriyanto 164

Shinta Hiflina Yuniari1 174

Shofiyatul lailiyah 97

Soemarno 77

Syafriza Akbar 148

Syavin Pristiwayuning Rachmadhany 44

Taukhid 164

Tita Divya Carolin 37

Tri Anugrah Yudesta 231

Tri Djoko Lelono 61

Usman 77

Yudistira Harisandi 198

Yuliana 28

Yusmia Widiastuti 126; 261

Zamdial 231 


\section{Subject Index}

\section{Volume 6 Issue Spesial July 2021}

\begin{tabular}{|c|c|c|}
\hline Abalon 52 & Kewirausahaan 126 & Perempuan 192 \\
\hline ADME/T 110 & Kinerja Usahatani 126 & Perikanan 44 \\
\hline Akuakultur 110 & Koloni 1 & perikanan tangkap 218 \\
\hline Amphora sp. 110 & Kontrol 1 & Perilaku 183 \\
\hline Anguilla spp. 164 & Komoditas Unggulan 61 & perilaku ekonomi 261 \\
\hline Bahan Organik 97 & komoditas unggulan Kabupaten & Perlakuan 1 \\
\hline bakso kerang 37 & Situbondo 218 & perubahan 198 \\
\hline Banyuwangi 119; 157 & Kopi 126 & pesisir Jember 245 \\
\hline Bencana 157 & Limbah Udang 97 & Pesisir Wongsorejo 174 \\
\hline Bengkulu 231 & loin 231 & pesisir,model 77 \\
\hline Berkelanjutan 44 & manajemen, pesisir 28 & Potensi Lestari 61 \\
\hline Besek ikan 192 & Mangrove $90 ; 134 ; 148 ; 174 ; 268$ & Rehabilitasi 134 \\
\hline Bioremediasi 97 & Maros 134 & Sidat 164 \\
\hline Blimbingsari 119 & Masyarakat 134 & Sonikasi 110 \\
\hline budaya 198 & masyarakat pesisir 119 & sosial 198 \\
\hline Budidaya Intensif 15 & Masyarakat Pesisir 183 & Sosial 77 \\
\hline Budidaya udang 44 & Mikroba 164 & sosial budaya 28 \\
\hline Dosis 1 & Mikroorganisme 97 & Status Pengusahaan 61 \\
\hline Ecotourism 148 & Mitigasi 157 & STELLA 61 \\
\hline Ekologi 77 & Muncar 157 & strategi 261 \\
\hline Ekonomi 77 & Muncar 37 & Strategi pelestarian 148 \\
\hline Ekonomi Masyarakat 183 & off fishing 261 & Strategi Pengembangan Usaha 90 \\
\hline ekowisata 268 & Pantai Cemara 148 & Tambak 97 \\
\hline Ekstensif 15 & Pantai Cemara 90 & teknik pendederan 52 \\
\hline Faktor Lingkungan Ekonomi 126 & Pantai Sari 268 & Tingkat Pengusahaan 61 \\
\hline H. squamata 52 & PASSonline 110 & tuna 231 \\
\hline Identifikasi 174 & Patogen 164 & Udang Vaname 15 \\
\hline industry 231 & pemberdayaan 208 & \\
\hline investasi 231 & pemberdayaan masyarakat 245 & \\
\hline Kaur 231 & Pemetaan 174 & \\
\hline keadaan sosial-ekonomi 119 & pendapatan 192 & \\
\hline Kelompok 44 & pendapatan 261 & \\
\hline kemandirian nelayan 208 & pengembangan 268 & \\
\hline kerajinan kayu 198 & pengrajin 192 & \\
\hline kesadaran 208 & peningkatan ekonomi 37 & \\
\hline
\end{tabular}


Deskripsi

Journal of Aquaculture Science (JoAS) terdaftar dengan nomor p-ISSN: 2550 - 0910, eISSN: 2579 - 4817, yang diterbitkan oleh Program studi Akuakulture, Fakultas Perikanan dan Kelautan, Universitas Airlangga.

Journal of Aquaculture Science (JoAS) telah terakreditasi oleh Direktorat Jendral Penguatan Riset dan Pengembangan, Kementrian Riset, Teknologi, dan Pendidikan Tinggi, Republik Indonesia dengan Nomor: 36/E/KPT/2019 berlaku sejak 29 April 2018.

Journal of Aquaculture Science (JoAS) adalah menyajikan artikel hasil penelitian, ulasan artikel, komunikasi singkat dan laporan teknis seputar Ilmu Perikanan dan Kelautan yang terbit dua kali setahun (April dan Oktober). Journal of Aquaculture Science merupakan media bagi peneliti, mahasiswa dan praktisi perikanan. Seluruh pemuatan artikel yang diterbitkan oleh Journal of Aquaculture Science melalui sistem Open Journal System (OJS). Informasi seputar pemuatan artikel dan petujunk penulisan tersedia dilaman website: https//joas.co.id.

VISI

Menjadi jurnal bereputasi nasional dan Internasional dalam bidang perikanan

\section{MISI}

1. Sebagai media perkembangan intelektualitas bagi civitas akademika dalam mendukung Universitas Airlangga menjadi World Class University;

2. Menyelenggarakan pengelolaan jurnal yang akuntabel dan berkualitas untuk meningkatkan jumlah produk intelektual berupa jurnal ilmiah;

3. Menjadi referensi unggulan bagi civitas akademika dan peneliti bidang perikanan kususnya budidaya perairan.

Lingkup Jurnal, budidaya perairan, reproduksi dan penyakit ikan, lingkungan budidaya dan perairan, dan biotechnology.

Bahasa Utama: Bahasa Indonesia

Tambahan: Bahasa Inggris

Artikel yang diterima oleh Journal of Aquaculture Science (JoAS) adalah:

1. Original Artikel

2. Artikel review

3. Short Comunication

4. Technical note 


\title{
DEWAN REDAKSI
}

\section{Ketua Dewan Redaksi}

Prayogo, S.Pi., M.P., Universitas Airlangga, Indonesia

Asisten Dewan Redaksi

Suciyono, S.St.Pi., M.P., Universitas Airlangga, Indonesia

Hapsari Kenconojati, S.Si., M.Si., Universitas Airlangga, Indonesia

\section{Anggota Dewan Redaksi}

Lailatul Lutfiyah, S.Pi., M.Si., Universitas Airlangga, Indonesia

Arif Habib Fasya, S.Pi., M.P., Universitas Airlangga, Indonesia

\author{
Staf Administrasi \\ Choirun Nisa, S.IIP, Universitas Airlangga, Indonesia \\ Rizki Dwi Akbar, Universitas Airlangga, Indonesia
}

\section{MITRA BESTARI}

Terima kasih kepada mitra bestari yang membantu memberikan review dan menilai pada Journal of Aquaculture Science

Prof. Dr. Mirni Lamid, drh., M.P., Universitas Airlangga, Indonesia

Dr. Endang Dewi Masithah, S.Pi., M.P, Universitas Airlangga, Indonesia

Dr. Waode Munaeni, S.Pi., M.Si, University of Halu Oleo, Kendari, Indonesia

Dr. Mugi Mulyono,S.St.Pi, M.S, Jakarta Fisheries University, Indonesia

Dr. Ruly Isfatul Khasanah, S.Si., M.P, UIN Sunan Ampel Surabaya, Indonesia

Dr. Aris Widagdo, A.Pi., M.Si, Politeknik Kelautan dan Perikanan Karawang, Indonesia

Dewi Nurhayati, S.Pi., M.Si, Universitas 17 Agustus 1945 Cirebon, Indonesia

Apriana Vinasyiam, S.Pi., M.Sc, Institut Pertanian Bogor, Indonesia

Arafik Lamadi, S.ST., M.P, Universitas Negeri Gorontalo, Indonesia

Darmawan Setia Budi, S.Pi., M.Si, Universitas Airlangga Banyuwangi, Indonesia

Wiwin Kusuma Atmaja Putra, S.Pi., M.Si, Universitas Maritim Raja Ali Haji, Indonesia

Rizal Akbar Hutagalung, S.Pi.,M.P, Politeknik Negeri Pontianak, Indonesia

Mohammad Faizal Ulkhaq, S.Pi., M.Si, Universitas Airlangga Banyuwangi. Indonesia

Gde Raka Angga Kartika, S.Pi.,M.P, Universitas Udayana, Indonesia

Abdul Qadir Jailani, S.Pi., M.P, Universitas Tidar, Indonesia

Muhammad Hanif Azhar, S.Pi., M.Si, Universitas Airlangga Banyuwangi, Indonesia 


\section{Petunjuk Penulis untuk Pengajuan Online}

\section{Cara Mendaftar Sebagai Penulis}

- Kunjungi Website http://joas.co.id/index.php/JoAS/index

- Klik pada link "Register".

- Isi semua informasi yang diperlukan di form registrasi.

- Semua fields yang memilik tanda '*' (bintang) wajib untuk diisi.

- User dapat mendaftar sebagai Reader dan/Author. Di bawah bidang "register as", bisa dipilih sebagai "Author" juga. Hanya user tersebut yang telah mendaftar sebagai "Author" dapat mensubmit manuscript secara online. Jika anda lupa mendaftar sebagai Author, maka anda dapat merubah role anda dari Reader menjadi Author. Untuk hal ini, maka setelah Login klik link "edit my profile". Dibawah judul "role", lalu pilih role sebagai Author.

- Setelah mengisi semua detail yang diperlukan, klik pada tombol register.

- Jika pendaftaran berhasil, anda dapat langsung login sebagai author dengan menggunakan username dan password yang telah anda daftarkan. Anda akan juga akan menerima email yang memberitahukan detail tentang pendaftaran anda.

\section{Cara Login dan apa itu Author's user home page?}

- Untuk login ke sistem, klik pada link login pada sub menu atas, lalu masukkan username dan password yang telah terdaftar.

- Setelah login maka akan muncul tampilan "user home page" dimana memiliki link untuk "Author", "Active article". \& "New Submission".

- Mengklik link "Author" akan membawa anda pada page dimana akan menunjukan link untuk "Active" \& "Archived" article.

- Untuk mengecek status atau detail dari article, klik link "Active". Untuk penyerahan artikel baru, klik link "New submission".

- Untuk merubah profil anda, klik pada link "Edit My Profile" dibawah bagian "My Account". Anda juga dapat merubah password anda di sini. 
Bagaimana cara penyerahan manuscript online?

Penyerahan online merupakan lima-langkah proses penyerahan seperti di bawah ini:
1. START
2. UPLOAD SUBMISSION
3. ENTER METADATA
4. UPLOAD SUPPLEMENTARY FILES
5. CONFIRMATION

Klik pada "New submission" (jika anda sudah pada halaman "user home page" setelah login) seperti yang di tunjukan pada gambar 1 di bawah.

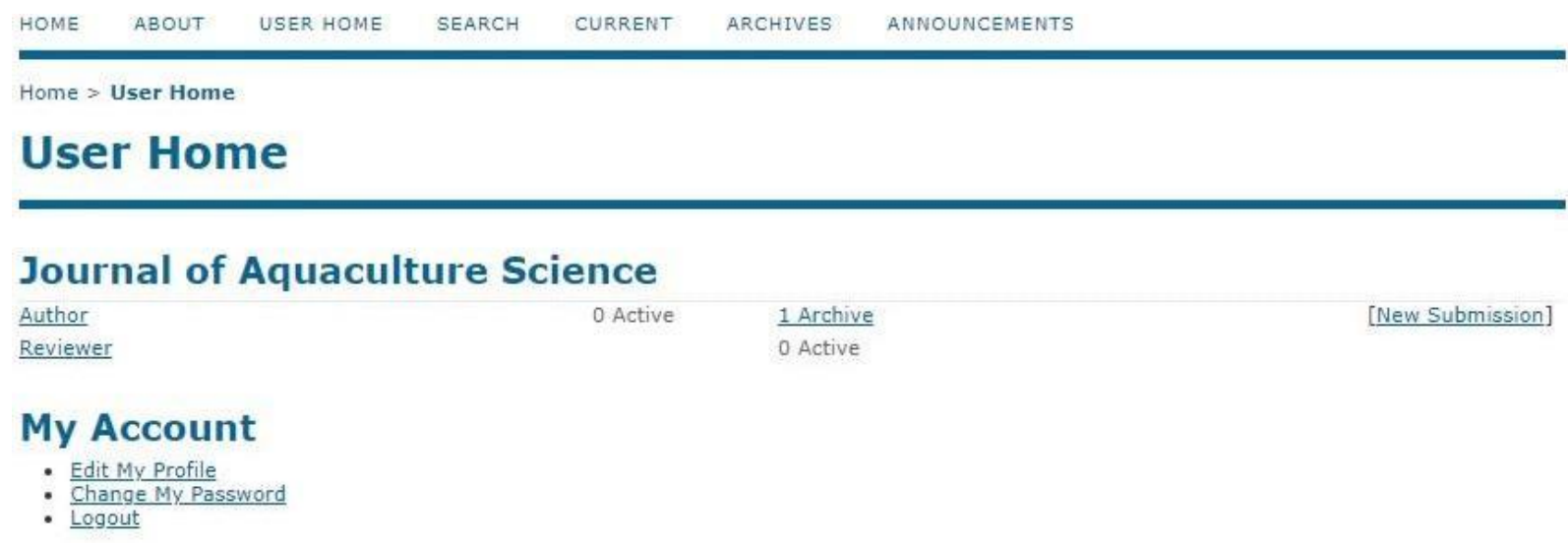

Gambar 1. Memulai penyerahan baru 
Lima-langkah proses penyerahan dijelaskan di bawah ini:

\section{Langkah 1 ; Memulai Penyerahan}

Submission Language : pilih bahasa artikel yang ingin anda serahkan.

Submission Checklist : Author harus menyetujui beberapa persyaratan JoAS.

Copyright Notice : Author harus menyetujui ketentuan pendaftaran hak cipta.

Journal Privacy Statement : Author harus menyetujui Journal Privacy Statement.

Comments for the Editor : Anda diperbolehkan menambahkan komen yang anda inginkan untuk editor.

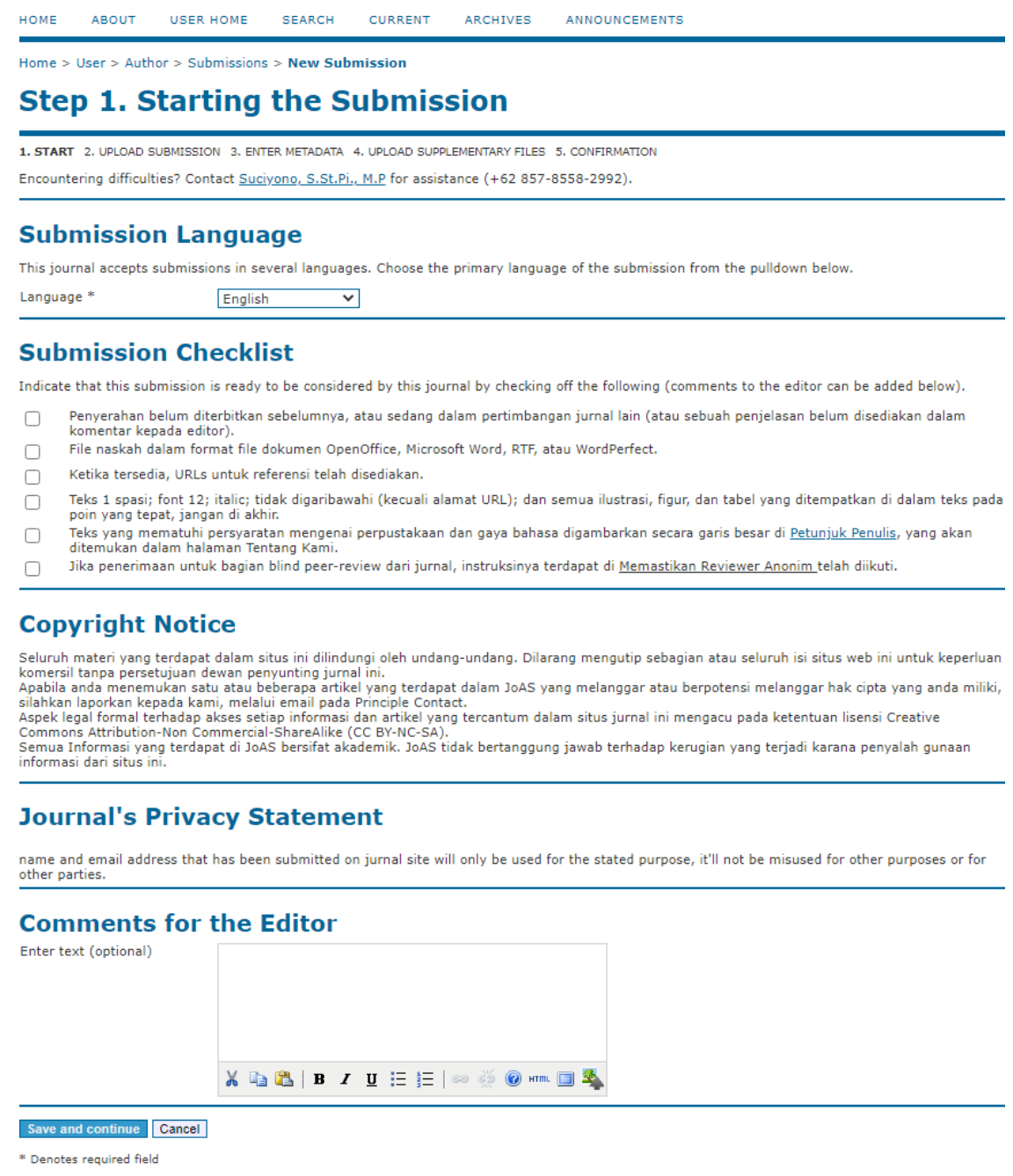

Gambar 2. Langkah pertama penyerahan 


\section{Langkah 2 : Mengunggah Naskah}

Submission File : Submission file merupakan dokumen manuscript anda. File submission seharusnya dalam bentuk dokumen .word karena untuk keperluan mengedit pada langkah selanjutnya. Usahakan file manuscript minimum. Jika ukuran file lebih besar, hapus beberapa gambar, tabel, kurva, dll dari dokumen utama untuk mengurangi ukuran file. Gambar, tabel, kurva, dll dapat diupload pada langkah 4 "Uploading Supplementary Files".

Choose File : klik pada "browse" atau "Choose File" untuk membuka Choose File Window untuk mencari file pada penyimpanan computer anda. Temukan file yang anda inginkan untuk diserahkan dan pilih file tersebut. Klik "open" pada Choose File Window, dimana menempatkan nama dari file tersebut di halaman ini.

Upload File : Jangan lupa untuk mengklik Upload, dimana mengupload file dari computer anda ke website jurnal dan menamainya sesuai ketentuan jurnal. Jika anda mengupload file yang salah, anda dapat mengganti file tersebut dengan mengupload ulang file baru.

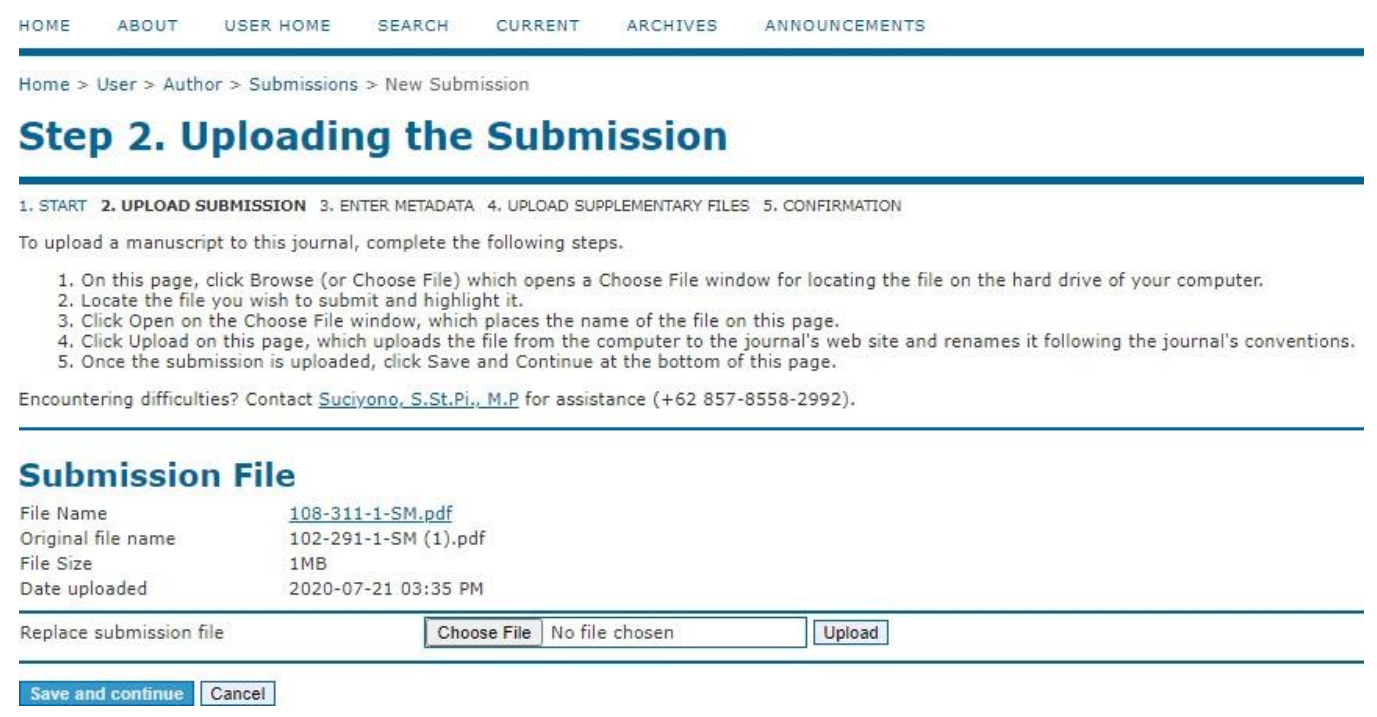

Gambar 3. Mengunggah file naskah

Saat penyerahan file berhasil di unggah, klik "save and continue" untuk ke langkah selanjutnya. 


\section{Langkah 3 : Mengisi Metadata Submission}

Author Details : bagian pertama dari cover metada author. Author yang telah melakukan penyerahan mengisi detail author seperti nama, email, organisasi, Negara, dll akan ditampilkan secara otomatis pada Author metadata. Klik tombol "add author" untuk menambahkan Author lain dan isi detail author.

Judul dan Sari : masukkan judul dan sari dari artikel. Tidak diperbolehkan menggunakan format judul seperti bold, italics, dll.

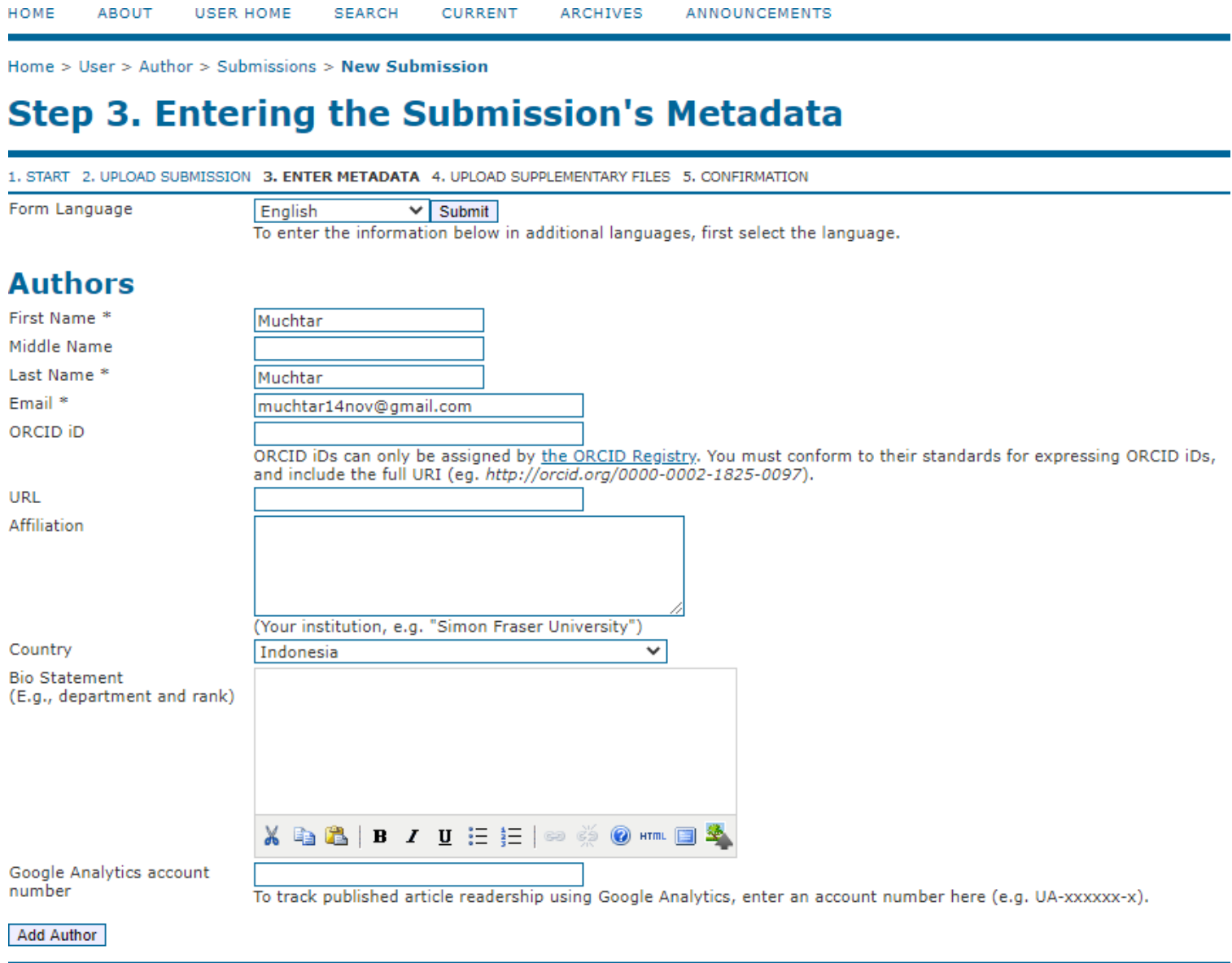

\section{Title and Abstract}

Title *

Abstract *

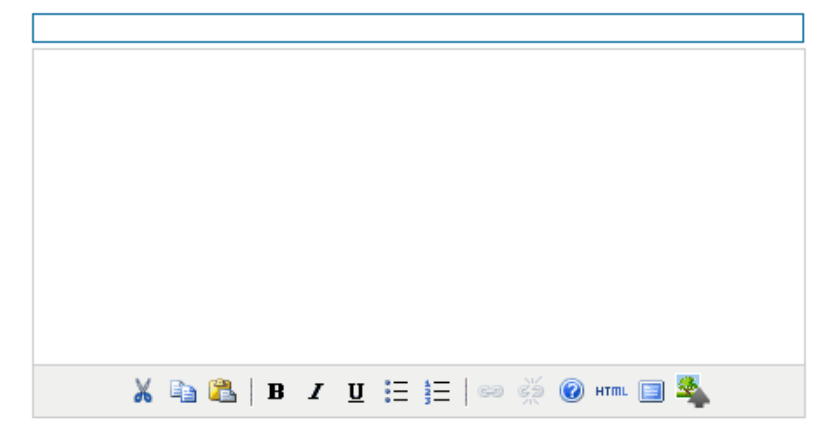

Gambar 4. Detail aithor, tittle dan sari metadata 
Indexing : menambahkan kata kunci dalam indexing section dimana dapat membantu dalam pencarian artikel.

Contributors and Supporting Agencies : mengidentifikasikan agencies (seseorang, organisasi, atau jasa) yang memiliki kontribusi terhadap konten atau menyediakan pembiayaan atau dukungan atas submission yang di serahkan.

References : Menyediakan daftar referensi terformat dalam karya karya yang dikutip dari submission ini.

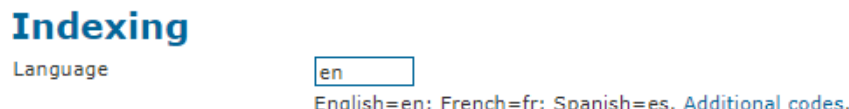

\section{Contributors and Supporting Agencies}

Identify agencies (a person, an organization, or a service) that made contributions to the content or provided funding or support for the work presented in this submission. Separate them with a semi-colon (e.g. John Doe, Metro University; Master University, Department of Computer Science).

Agencies

\section{References}

Provide a formatted list of references for works cited in this submission. Please separate individual references with a blank line.

References

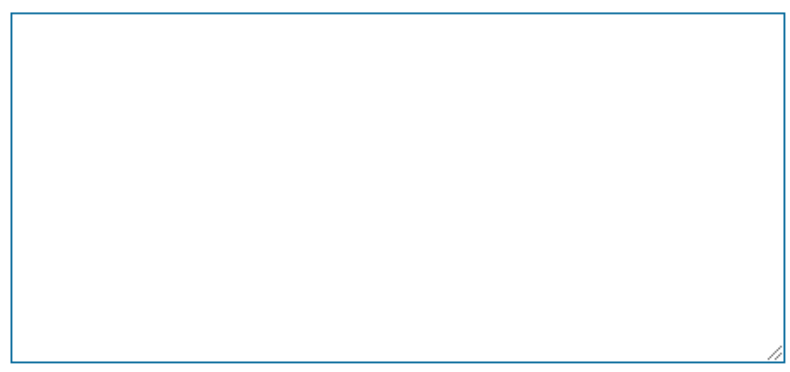

Gambar 5. Indexing, Contributors, references metadata 


\section{Langkah 5 : Mengunggah Supplementary files}

Langkah ini merupakan opsional, supplementary files dapat diunggah dalam bentuk format seperti TIF, JPG, GIF, Word, dll.

home about user home SEARCh CURRent archives anNouncements

Home > User > Author > Submissions > New Submission

\section{Step 4. Uploading Supplementary Files}

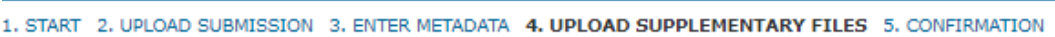

This optional step allows Supplementary Files to be added to a submission. The files, which can be in any format, might include (a) research instruments, (b) data sets, which comply with the terms of the study's research ethics review, (c) sources that otherwise would be unavailable to readers, (d) figures and tables that cannot be integrated into the text itself, or other materials that add to the contribution of the work.

\begin{tabular}{|c|c|c|c|c|c|c|}
\hline ID & TITLE & \multicolumn{3}{|c|}{ ORIGINAL FILE NAME } & DATE UPLOADED & ACTION \\
\hline 15 & Untitleda & \multicolumn{3}{|c|}{ 102-291-1-SM (1).pdf } & $07-21$ & EDIT | DELETE \\
\hline Uplo & supplementary file & Choose File & No file chosen & \begin{tabular}{|l|} 
Upload \\
\end{tabular} & & \\
\hline
\end{tabular}




\section{Langkah 4A : Menambahkan Supplementary Files Metadata}

Untuk mengindexkan material tambahan ini, harap menyediakan informasi metadata untuk file tambahan yang akan diunggah.

home about USER hOME SEARCH CURRENT ARCHIVES ANNOUNCEMENTS

Home $>$ User $>$ Author $>$ Submissions $>$ New Submission

\section{Step 4a. Add a Supplementary File}

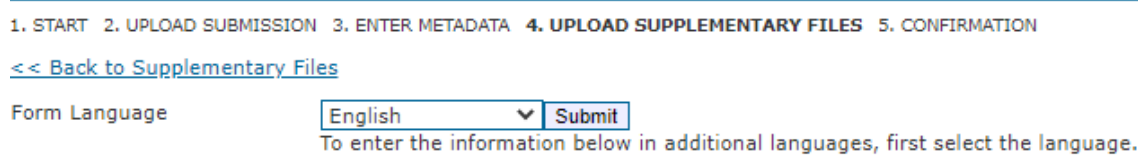

\section{Supplementary File Metadata}

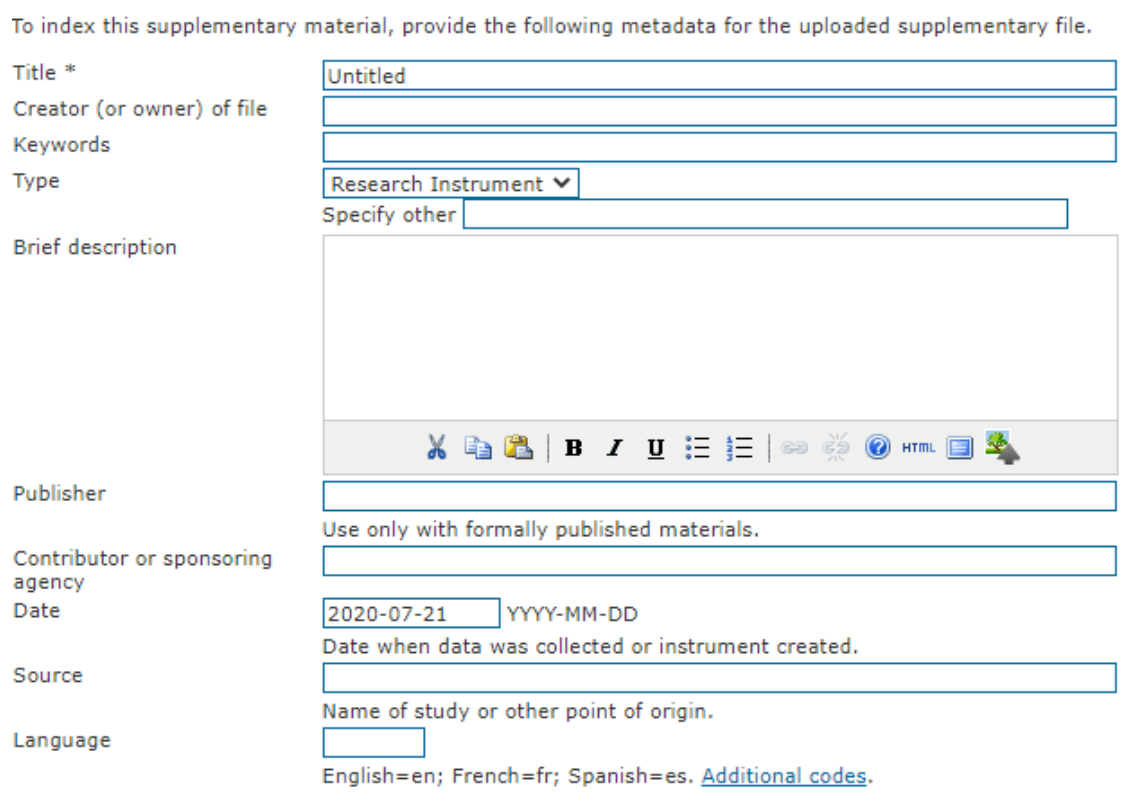

\section{Supplementary File}

\begin{tabular}{|c|c|c|}
\hline File Name & $\underline{108-312-1-S P . p d f}$ & \\
\hline Original file name & 102-291-1-SM (1).pdf & \\
\hline Date uploaded & 2020-07-21 03:37 PM & \\
\hline Replace file & Choose File No file chosen & ad file. \\
\hline
\end{tabular}

\section{Save and continue Cancel}

* Denotes required field

Gambar 7. Supplementary file metadata

Klik pada "save and continue" untuk menuju langkah 5 


\title{
Langkah 5 : Konfirmasi Penyerahan
}

Anda akan melihat ringkasan file seperti ditunjukkan pada gambar 8 di bawah dimana memiliki daftar file manuscript \& supplementary file (jika diserahkan). Klik pada "Finish Submission" untuk menyelesaikan penyerahan. Klik pada "Active Submission" untuk melihat status dari artikel anda. Anda akan menerima pemberitahuan pada email dan dapat melihat proses penyerahan anda melalui proses editorial dengan log in pada jurnal website.

home about USER hOME SEARCh CURRENT ARCHIVES ANNOUNCEMENTS

Home > User > Author > Submissions > New Submission

\section{Step 5. Confirming the Submission}

1. START 2. UPLOAD SUBMISSION 3. ENTER METADATA 4. UPLOAD SUPPLEMENTARY FILES 5. CONFIRMATION

To submit your manuscript to Journal of Aquaculture Science click Finish Submission. The submission's principal contact will receive an

acknowledgement by email and will be able to view the submission's progress through the editorial process by logging in to the journal web site. Thank you for your interest in publishing with Journal of Aquaculture Science.

\section{File Summary}

\begin{tabular}{|c|c|c|c|c|}
\hline ID & ORIGINAL FILE NAME & TYPE & FILE SIZE & DATE UPLOADED \\
\hline 311 & $102-291-1-S M(1), P D F$ & Submission File & $1 \mathrm{MB}$ & $07-21$ \\
\hline 312 & $102-291-1-\mathrm{SM}$ (1).PDF & Supplementary File & $1 \mathrm{MB}$ & $07-21$ \\
\hline
\end{tabular}

\section{Author Fees}

\author{
This journal charges the following author fees. \\ : 0.00 (IDR) PAY NOW \\ : 300.00 (IDR) PAY NOW \\ $: 0.00$ (IDR)
}




\section{Bagaimana cara untuk melihat proses penyerahan?}

Author akan diberitahukan perihal proses penyerahan dengan email otomatis. Online publishing system memberitahukan setiap langkah langkah penting dari proses review dan editing. Author harus login pada sistem untuk melihat proses dari penyerahan dan mengambil tindakan yang diperlukan.

Active Submission : setelah login. Klik pada link "author". Halaman ini akan memunculkan dua tab atau link -satu untuk "active" \& "archive". "active" akan menunjukkan daftar artikel dan detail artikel tersebut. "archive" akan menunjukan daftar dari artikel yang telah dipublikasikan maupun ditolak.

Article Status : Setelah penyerahan artikel berhasil, maka sistem akan menunjukkan statusnya sebagai "Awaiting Assignment". Ketika editor mengirimkan artikel untuk peer review, maka statusnya akan berubah menjadi "in review". Ketika artikel telah diterima untuk dipublikasikan, maka statusnya akan berubah menjadi "In editing”.

Daftar dari setiap status dijelaskan pada tabel dibawah ini :

\begin{tabular}{|l|l|}
\hline \multicolumn{1}{|c|}{ Status } & \multicolumn{1}{|c|}{ Description } \\
\hline $\begin{array}{l}\text { Awaiting } \\
\text { Assigment }\end{array}$ & $\begin{array}{l}\text { Penyerahan telah diselesaikan oleh anda. Anda saat ini tidak dapat menghapus } \\
\text { submission dari sistem oleh anda sendiri. Editor dapat melihat submission tersebut, } \\
\text { dan akan diberikan ke editor atau editor bagian. Author masih dapat memberikan } \\
\text { pembaharuan pada detail metadata seperti author, judul, abstract dan kata kunci } \\
\text { sampai artikel ditugaskan oleh editor }\end{array}$ \\
\hline Incomplete & $\begin{array}{l}\text { Submission masih belum selesai. Anda telah meninggalakan submission sebelum } \\
\text { menyelesaikan langkah langkah submission. Anda dapat kembali ke proses akhir } \\
\text { yang anda tinggalkan untuk melanjutkan submission tersebut. }\end{array}$ \\
\hline In Review & $\begin{array}{l}\text { Penyerahan saat ini dalam proses review. Anda akan menerima pemberitahuan atas } \\
\text { keputusan review article }\end{array}$ \\
\hline In Editing & $\begin{array}{l}\text { Penyerahan telah selesai dari proses review dan telah diterima untuk di } \\
\text { publikasikan. Artikel akan melalui sistem copyediting, layout editing dan } \\
\text { proofreading processes }\end{array}$ \\
\hline Archived & \begin{tabular}{l} 
Penyerahan artikel telah ditolak. Artikel sekarang tidak di proses aktif. \\
\hline
\end{tabular} \\
\hline
\end{tabular}


Article Details : Setelah login, click pada judul artikel untuk melihat detail dari artikel. Halaman ini akan menunjukan tiga tabs (link), Summary, Review, \& Editing. Summary menunjukkan dari ringkasan artikel dan metadata.

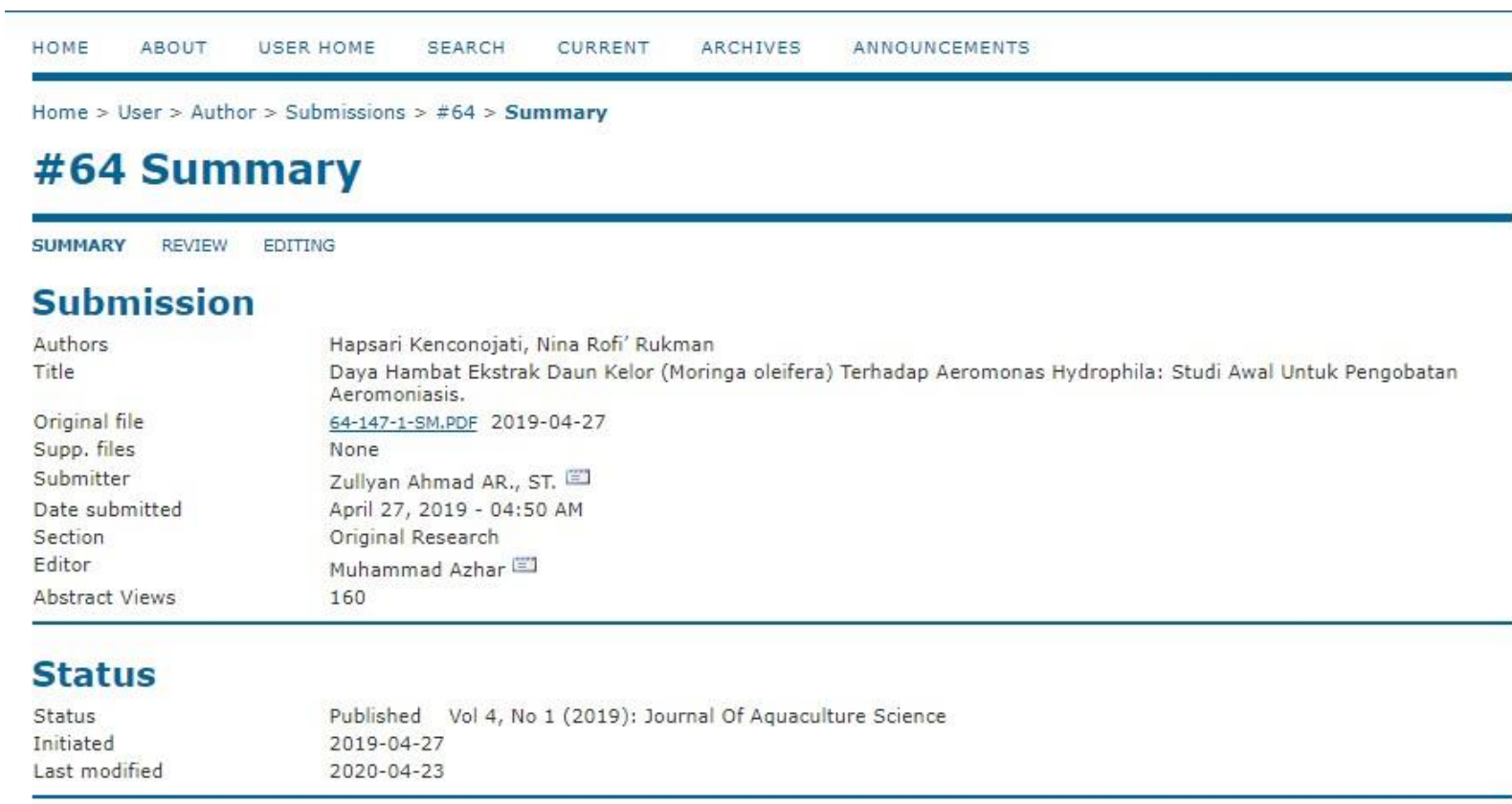

\section{Submission Metadata}

$\begin{array}{ll}\text { Authors } & \\ \text { Name } & \text { Hapsari Kenconojati } \boxminus \\ \text { Affiliation } & \text { Universitas Airlangga } \\ \text { Country } & \text { Indonesia } \\ \text { Bio Statement } & - \\ \text { Principal contact for editorial correspondence. } \\ \text { Name } & \text { Nina Rofi' Rukman } \boxminus \\ \text { Affiliation } & \text { Universitas Airlangga } \\ \text { Country } & - \\ \text { Bio Statement } & -\end{array}$

Title and Abstract

Title Daya Hambat Ekstrak Daun Kelor (Moringa oleifera) Terhadap Aeromonas Hydrophila: Studi Awal Untuk Pengobatan

Abstract Aeromoniasis.

The aim of this study was to know antibacterial potency of ethanolic extract of drumstick leaf against Aeromonas hydrophila in vitro. Total flavonoid, alkaloid, tannin and saponin of the ethanolic drumstick leaf extract were analyzed using spectrophotometry. Antibacterial activity test was carried out by disk diffusion and tube dilution method. Ethanolic extract of drumstick leaf contained flavonoids total as $71.9 \mathrm{mg}$ quercetine equivalent $/ \mathrm{g}$, alkaloids total as $3 \mathrm{mg}$ quinine equivalent/g, tannin as $24.7 \mathrm{mg}$ tannic acid equivalent $/ \mathrm{g}$ and saponin as $44.4 \mathrm{mg} / \mathrm{g}$. The result of antibacterial test showed significant inhibition of Aeromonas hydrophila by drumstick leaf extract $(P<0.05)$. The highest inhibition zone was produced by drumstick leaf extract with concentration of $100 \%$ which is $9.9 \pm 0,162 \mathrm{~mm}$. The minimum inhibition concentration (MIC) of drumstick leaf extract is $3.125 \%$, while the minimum bactericidal concentration (MBC) is $6.25 \%$. Based on this study, it can be concluded that drumstick leaf can be used as an alternative natural product of antibacterial agent which can be applied especially in aquaculture.

Indexing

Language

Supporting Agencies

Agencies

References

References

Gambar 9. Summary 
Tab kedua "review" menunjukkan status dari proses review
HOME
ABOUT
USER HOME
SEARCH
CURRENT
ARCHIVES

Home > User > Author > Submissions > $\# 64$ > Review

\section{\#64 Review}

SUMMARY REVIEW EDITING

\section{Submission}

\begin{tabular}{ll} 
Authors & Hapsari Kenconojati, Nina Rofi' Rukman $\boxminus$ \\
Title & Daya Hambat Ekstrak Daun Kelor (Moringa oleifera) Terhadap Aeromonas Hydrophila: Studi Awal Untuk Pengobatan \\
Section & Aeromoniasis. \\
Editor & Original Research \\
\hline
\end{tabular}

\section{Peer Review}

\section{Round 1}

Review Version

Initiated

Last modified

Uploaded file

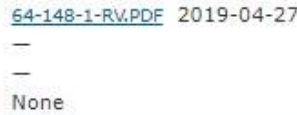

\section{Editor Decision}

Decision

Notify Editor

Editor Version

Author Version

Upload Author Version
Accept Submission 2019-04-27

曰Editor/Author Email Record $\square$ No Comments

None

None

\begin{tabular}{|l|l|l|l|l|}
\hline Choose File No file chosen & Upload \\
\hline
\end{tabular}

Gambar 10. Review 
Penulis dapat melihat versi editor dari manuscript tersebut dan dapat mengupload ulang versi author dari manuscript tersebut jika diminta untuk revisi dari editor.

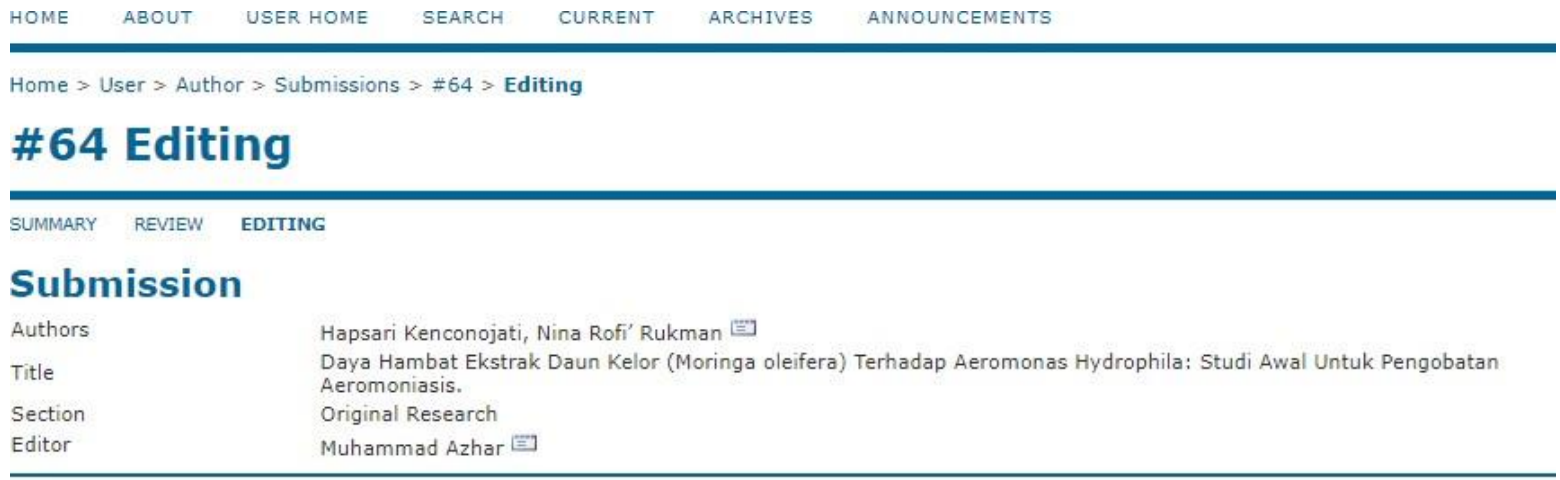

\section{Copyediting}

\section{COPYEDIT INSTRUCTIONS}

Copyeditor Non

REVIEW METADATA

None

1. Initial Copyedit

File: None

2. Author Copyedit

File: None

\begin{tabular}{l} 
File: None \\
\hline Choose File No file chosen
\end{tabular}

3. Final Copyedit
File: None

Copyedit Comments $\square$ No Comments

\section{Layout}

Layout Editor

Layout Version

None

None

Galley Format

1. PDF (Bahasa Indonesia) VIEW PROOF

Supplementary Files

\begin{tabular}{l} 
REQUEST \\
- \\
FILE \\
$\begin{array}{l}\text { 64-158-2-PB,PDF } \\
\text { FILE }\end{array}$ 2019-06-24 \\
\multicolumn{2}{c}{ None }
\end{tabular}

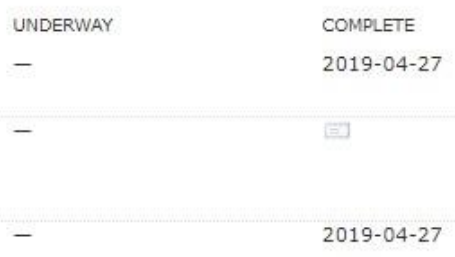

Layout Comments $\nabla_{\text {No Comments }}$

\section{Proofreading}

Proofreader

REVIEW METADATA

Muhammad Hanif Azhar

Author

2. Proofreader

3. Layout Editor

Proofreading Corrections $\square$ No Comments

REQUEST
-
$2019-04-27$
$2019-04-27$

$\begin{array}{ll}\text { UNDERWAY } & \text { COMPLETE } \\ - & \square \\ - & 2019-04-27 \\ - & 2019-04-27\end{array}$

PROOFING INSTRUCTIONS

\section{กคลล}

\section{Technical Support}

untuk setiap pertanyaan mengenai technical support atau bantuan dalam online submission, harap mengirimkan email pada joas@psdku.unair.ac.id 


\title{
Judul ditulis dengan huruf capital di awal kata (In Bahasa)
}

Title in Indonesia (Times New Roman, Font 14)

Judul dalam Bahasa Indonesia (Times New Roman, Font 14)

Title in English (Times New Roman, Font 14)

Judul dalam Bahasa Inggris (Times New Roman, Font 14)

Name of Authors (Full name) (Times New Roman Font 11 pt) Author ${ }^{1}$, Author ${ }^{2 *}$

Name penulis (Nama Lengkap) (Times New Roman, Font 11 pt) Author ${ }^{1}$, Author ${ }^{2 *}$

Name Institution (Departement, Faculty and address) (Times New Roman, Font 10 pt)

Name Institusi (Departemen, Fakultas dan Alamat) (Times New Roman, Font 10 pt)

*Corresponding Author : Email (Times New Roman, Font 10 pt)

*Koresponding Author : Email (Times New Roman, Font 10 pt)

\begin{abstract}
Abstrak (In Indoensia) (Times New Roman, Font 10 pt)
Written in Indonesia and English. Abstracts include 3-5 keywords sorted according to their importance. Abstract contains a summary of the manuscript, covering all writing without trying to specify each part. Avoid using abbreviations.

Kata kunci: first, second, third, fourth, fifth.

Ditulis dalam Bahasa Indonesia dan Bahasa Inggris. Abstrak mencakup 3-5 kata kunci yang diurutkan sesuai dengan kepentingannya. Abstrak berisi ringkasan naskah, yang mencakup semua tulisan tanpa mencoba menentukan setiap bagian. Hindari menggunakan singkatan.
\end{abstract}

Kata kunci: pertama, kedua, ketiga, keempat, kelima

Abstract (In English) (Times New Roman, Font 10 pt)

Written in Indonesia and English. Abstracts include 3-5 keywords sorted according to their importance. Abstract contains a summary of the manuscript, covering all writing without trying to specify each part. Avoid using abbreviations.

Kata kunci: first, second, third, fourth, fifth.

Ditulis dalam Bahasa Indonesia dan Inggris. Abstrak mencakup 3-5 kata kunci yang diurutkan sesuai dengan kepentingannya. Abstrak berisi ringkasan naskah, yang mencakup semua tulisan tanpa mencoba menentukan setiap bagian. Hindari menggunakan singkatan.

Kata kunci: pertama, kedua, ketiga, keempat, kelima 
Latar Belakang (Introduction) (Times New Roman, Font 10 pt)

Contains the scope, background of the objectives and benefits of the study. This section should provide background so that the reader can understand and assess the results of the study without reading previous reports relating to the topic. Give literature that can support the discussion.

Berisi ruang lingkup, latar belakang tujuan dan manfaat penelitian. Bagian ini harus memberikan latar belakang sehingga pembaca dapat memahami dan menilai hasil penelitian tanpa membaca laporan sebelumnya yang berkaitan dengan topik tersebut. Berikan literatur yang sesuai dan dapat mendukung diskusi.

\section{Materi dan Metode (Materials and Methods)}

Describe in detail and clearly the design of the study, the method of treatment, the materials used and the method of work carried out, including statistical methods and an explanation of the certificate of ethical conduct of the animal if needed. The method of work submitted should contain sufficient information so as to enable the research to be repeated successfully.

Menjelaskan secara rinci dan jelas desain penelitian, metode pemeiharaan, bahan yang digunakan dan metode kerja yang dilakukan, termasuk metode statistik dan penjelasan tentang sertifikat perilaku etis hewan jika diperlukan. Metode kerja yang disampaikan harus mengandung informasi yang cukup sehingga memungkinkan penelitian diulangi dengan sukses.

\section{Hasil dan Pembahasan (Results and Discussions)}

Presented jointly and discussed clearly the results of the study. The results of the research can be presented in written form in a script, table or picture. Reduce the use of graphics if it can be explained in the text. Limit the use of photos, present photos that clearly describe the results obtained. Pictures and tables must be numbered and quoted in the text. Photos can be sent in JPG, JPEG and PNG formats. The result of processing data is sent in a file separate from the scientific script file and accompanied by the name of the program and basic data for compiling the graph. The discussion presented should contain an interpretation of the results obtained and the discussion relating to previous reports. Avoid repeating statements that have been conveyed to methods, results and other information that has been presented in the introduction.

Disajikan bersama dan membahas dengan jelas hasil penelitian. Hasil penelitian dapat disajikan dalam bentuk tertulis dalam naskah, tabel atau gambar. Kurangi penggunaan grafik jika dapat dijelaskan dalam teks. Batasi penggunaan foto, sajikan foto yang menggambarkan dengan jelas hasil yang diperoleh. Gambar dan tabel harus diberi nomor dan dikutip dalam teks. Foto dapat dikirim dalam format JPG, JPEG, dan PNG. Hasil pemrosesan data dikirim dalam file yang terpisah dari file skrip ilmiah dan disertai dengan nama program dan data dasar untuk menyusun grafik. Diskusi yang disajikan harus berisi interpretasi hasil yang diperoleh dan diskusi yang berkaitan dengan laporan sebelumnya. Hindari pengulangan pernyataan yang telah disampaikan kepada metode, hasil dan informasi lain yang telah disajikan dalam pendahuluan.

\section{Kesimpulan (Conclusion) (Times New Roman, Font 10 pt)}

Must be specific, clear and answer the problem. Presented separately from the results and discussion.

Harus spesifik, jelas, dan menjawab permasalahannya. Disajikan secara terpisah dari hasil dan diskusi. 
Ucapan Terima Kasih (Acknowledgments) (Times New Roman, Font 10 pt)

Aimed at those who fund research and to reward institutions and individuals who have helped research or the process of scientific writing.

Ditujukan untuk mereka yang mendanai penelitian dan untuk memberi penghargaan kepada institusi dan individu yang telah membantu dalam penelitian atau proses penulisan ilmiah.

Bibliografi (Bibliography) (Times New Roman, Font 10 pt)

Alphabetically arranged according to name and year of publication. Abbreviation of magazine/journal based on the procedures used by each journal. The proportion of bibliography: scientific journals/magazines at least $60 \%$ and textbooks $40 \%$. Example of writing a bibliography:

- Journal: Verschuere L, Rombaut G, Sorgeloos P, Verstraete W. 2000. Probiotic Bacteria as Biological Control Agents in Aquaculture. Microbiology and Molecular Biology Reviews, 64(4): 655-671.

- Article DOI: Jin, E.S. \& Melis, A. Biotechnol. Bioprocess Eng. (2003) 8: 331. https://doi.org/10.1007/BF02949276.

- Book: Rai MK, Carpinella C. 2006. Naturally Occurring Bioactive Compounds. Elsevier, Amsterdam.

- Proceeding: Alikodra HS. 2000. Biodiversity for development of local autonomous government. In: Setyawan AD, Sutarno (eds). Toward Mount Lawu National Park; Proceeding of National Seminary and Workshop on Biodiversity Conservation to Protect and Save Germplasm in Java Island. Sebelas Maret University, Surakarta, 17-20 July 2000.

- Undergraduate Tesis, Tesis, Dissertation: Johari HS. 2009. Analisis Pencemaran Logam Berat $\mathrm{Cu}, \mathrm{Cd}$, dan $\mathrm{Pb}$ di Perairan Kabupaten Administrasi Kepulauan Seribu Provinsi Jakarta [tesis]. Bogor (ID): Institut Pertanian Bogor..

- Online Document: Balagadde FK, Song H, Ozaki J, Collins CH, Barnet M, Arnold FH, Quake SR, You L. 2008. A synthetic Escherichia coli predator-prey ecosystem. Mol Syst Biol 4: 187. www.molecularsystemsbiology.com [21 April 2015].

Secara alfabet diatur menurut nama dan tahun publikasi. Singkatan majalah / jurnal berdasarkan prosedur yang digunakan oleh masing-masing jurnal. Proporsi bibliografi: jurnal ilmiah / majalah setidaknya $60 \%$ dan buku teks $40 \%$. Contoh penulisan daftar pustaka:

- Jurnal: Verschuere L, Rombaut G, Sorgeloos P, Verstraete W. 2000. Probiotic Bacteria as Biological Control Agents in Aquaculture. Microbiology and Molecular Biology Reviews, 64(4): 655-671.

- Artikel DOI: Jin, E.S. \& Melis, A. Biotechnol. Bioprocess Eng. (2003) 8: 331. https://doi.org/10.1007/BF02949276.

- Buku: Rai MK, Carpinella C. 2006. Naturally Occurring Bioactive Compounds. Elsevier, Amsterdam.

- Prosiding: Alikodra HS. 2000. Biodiversity for development of local autonomous government. In: Setyawan AD, Sutarno (eds). Toward Mount Lawu National Park; Proceeding of National Seminary and Workshop on Biodiversity Conservation to Protect and Save Germplasm in Java Island. Sebelas Maret University, Surakarta, 17-20 July 2000.

- Skripsi, Tesis, Desertasi: Johari HS. 2009. Analisis Pencemaran Logam Berat $\mathrm{Cu}, \mathrm{Cd}$, dan $\mathrm{Pb}$ di Perairan Kabupaten Administrasi Kepulauan Seribu Provinsi Jakarta [tesis]. Bogor (ID): Institut Pertanian Bogor.. 
- Dokumen Online: Balagadde FK, Song H, Ozaki J, Collins CH, Barnet M, Arnold FH, Quake SR, You L. 2008. A synthetic Escherichia coli predator-prey ecosystem. Mol Syst Biol 4: 187. www.molecularsystemsbiology.com [21 April 2015]. 